Висока школа струковних студија

за образовање васпитача, Кикинда;

Универзитет у Београду, Факултет политичких наука -

Одсек за новинарство и комуникологију, Београд

DOI 10.5937/kultura2069040A

УДК 316.776:077

$07: 316.7$

оригиналан научни рад

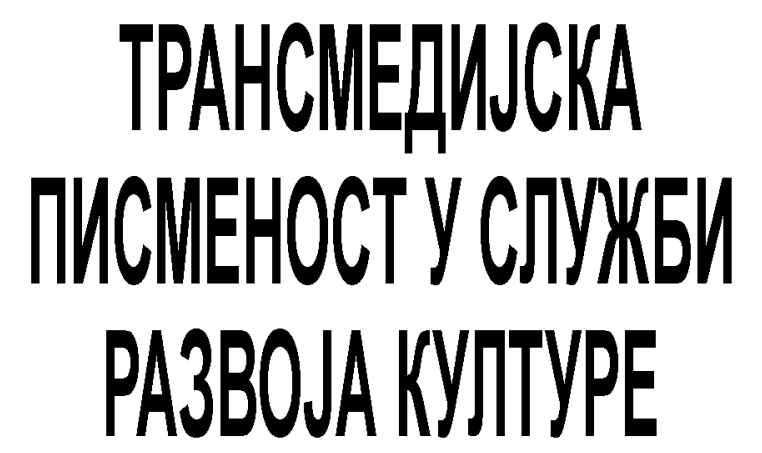

Сажетак: У овом раду разматрамо промене изазване новим комуникационим технопогијама које омогућавају све већу партиципацију просечних корисника интернета у сфери културне продукиије. Користећи перспективу пирамиде партиципаиије, представљамо различите облике остваривања учешћа корисника у култури у зависности од нивоа слободе који остварују, односно структурираности односа партиципације. Главни аргумент рада јесте да се развој културе може поспешивати са повећавањем партиципауије у културној продукцији. У складу са тим повезујемо пирамиду партиципације са компетенцијама које припадају трансмедијској писмености, како бисмо указали на потенцијал који трансмедијско описменаване може имати на обогаћиваье глобалне културе.

Кључне речи: онлајн партиципаиија, култура, уметност, трансмедијска писменост

\title{
$Y_{60 d^{1}}$
}

Са развојем дигиталних средстава комуникације, долази до укључења и повезаности све већег броја корисника у глобалну информационо-комуникациону мрежу и до њихових

1 Рад је настао као резултат истраживања у оквиру Републичког пројекта Дигиталне медијске технологије и друитьено образовне промене 47020 , Филозофског факултета у Новом Саду. Пројекат финансира Министарство просвете, науке и технолошког развоја Републике Србије. 
честих интеракција. Некада доминантно једнострана, масовна комуникација са мало повратних информација од стране хетерогене и анонимне публике преображава се у интерактивну комуникацију путем које публика ко-креира и размењује мноштво разнородних порука и садржаја ${ }^{2}$. Осим медија и других комуникационих и културних центара, у продукцији садржаја који круже глобалном мрежом активно учествују и некадашњи пасивни корисници медија. Данас скоро сви корисници интернета поседују могућност да производе оригиналан, или преузимају, мењају и редистрибуирају садржај са мреже. Поред изражавања личних мишљења и идеја, корисници интернета се све више креативно исказују кроз различите форме, које укључују чак и креирање алтернативних верзија стварности. Осим тога, мање активној и креативној публици, на располагању су алати који омогућавају да се постојећи садржаји надограћују. Кроз ове процесе корисници адаптираним садржајима додељују нова значења и смештају га у нови комуникациони контекст.

Партиципација представља један од кључних појмова кроз који се сагледавају могућности, начини и потенцијали учествовања корисника у комуникационим и креативним процесима. У овом раду полазимо од општег појма партиципације који подразумева независно, интерактивно и проактивно учествовање корисника у медијима и посредством медиja, ${ }^{3}$ која као резултат има увећавање људског знања ${ }^{4}$ односно изградњу и јачање друштвених веза. ${ }^{5}$

Циљ овог рада је да укаже на значај трансмедијског описмењавања корисника као предуслова за остваривање потенцијала партиципације за увећање дигиталне културне баштине. За ту сврху најпре уводимо појам културне партиципације, и објашњавамо како се одвија културна продукција кроз заједничке активности корисника у виртуелним окружењима (попут друштвених мрежа, вики апликација, блогова, форума, сарадничких онлајн игара итд.). Затим указујемо на слојевитост културне партиципације, односно представљамо пирамиду могућег учествовања у заједничком креирању

2 Arsenijević, J. i Andevski, M. Kreativnost u prostoru interneta, u: Digitalne medijske tehnologije i društveno-obrazovne promene 5, ur. Pralica, D. i Šinković, N. (2015), Filozofski fakultet: Novi Sad, str. 11-21.

3 Livingstone, S. (2015) Digital Skills for EU Citizens and Consumers; преузето 2. 12. 2020. са URL адресе: http://eprints.lse.ac.uk/80765/.

4 Hartley, J. (2012) Digital Futures for Cultural and Media Studies, WileyBlackwell.

5 Zukin, C., Keeter, S., Andolina, M., Jenkins, K., Delli, C. and Michael, X. (2006) A New Engagement? Political Participation, Civic Life, and the Changing American Citizen, Oxford University Press. 
садржаја, како бисмо истакли улогу трансмедијске писмености у спречавању јаза партиципације. Поред тога, рад аргументује да се компетенције за партиципацију не одражавају само на способност учешћа у култури, већ на све аспекте живота и рада који се данас одвијају на мрежи.

Наиме, активно учешће у дигиталним комуникационим и креативним процесима и заједничко креирање садржаја, захтевају од корисника да константно развијају нове вештине и способности, као и културу партиципације. Ове компетенције, односно способности за партиципацију у савременом дигиталном, медијатизованом друштву, обједињене су под појмом који се назива трансмедијска писменост. Трансмедијска писменост је скуп способности и знања појединца да пронађе, критички процени и анализира информације путем медија свих врста, повеже се и сарађује са другим корисницима, успешно обликује и посредује медијски садржај, ${ }^{6}$ тј. да стратешки и безбедно користи дигиталне медије и технологију како би решавао проблеме и остваривао академске, стручне, личне и друштвене циљеве. ${ }^{7}$ Овај феномен постаје предмет учесталих полемика и дискусија у разним контекстима, те се у својој интердисциплинарности, у професионалним и научним круговима често јавља и под другим именима: мултимедијска писменост, трансписменост, ${ }^{8}$ нова медијска писменост, ${ }^{9}$ дигитална писменост ${ }^{10}$ или нова писменост ${ }^{11}$. Дигитална писменост је концепт који се последњих година убрзано развија и проширује те осим техничке компетентности обухвата и шири скуп способности употребе дигиталних медија за несметано функционисање и учествовање у савременом друштву, друштвене вештине сарадње и комуницирања, креативне вештине стварања новог садржаја, вештине етичког коришћења медија и интеракције са другима као и способност безбедне употребе

6 Hobbs, R. (2010) Digital Media Literacy: A Plan of Action, New Delhi: Aspen Institute.

7 Grech, A. (2014) Malta National Lifelong Learning Strategy 2020; Преузето 12. марта 2018. године са сајта: http://www.ncte.org/library/nctefiles/resources/journals/ej/1026-jul2013/ej1026longer.pdf

8 Fleming, L. (2013) Expanding Learning Opportunities with Transmedia Practices: Inanimate Alice as an Exemplar, Journal of Media Literacy Education 5 (2) pp. 370-377.

9 Jenkins, H., Purushotma, R., Weigel, M., Clinton, K. and Robinson, A. (2009) Confronting the Challenges of Participatory Culture: Media Education for the 21st Century, Cambridge, MA: The MIT Press.

10 Spicer, B. (2017) Digital Literacy: The New Pillar of a Child's Education? Преузето 18. јула 2020. године са сајта: https://blog.myon.com/blogpost/digital-literacy-new-pillar-child $\% \mathrm{E} 2 \% 80 \% 99$ s-education

11 Hull, G. (2004) Youth culture and digital media: New literacies for new times, Research in the Teaching of English, 38(2), pp. 229-233. 
технологије. У том смислу, концепт се преплиће са појмом трансмедијске писмености који је у чешћој употреби у студијама медија, културе и комуникологије ${ }^{12}$. Међутим, без обзира на концептуалну неуједначеност, скуп вештина које се подводе под трансмедијску, односно дигиталну писменост, представљају предуслов за такозвано дигитално грађанство. ${ }^{13}$

И док се ове способности донекле стичу самом праксом коришћења дигиталних медија у медијским, партиципативним токовима - путем информалног учења - ове вештине треба сваки појединац једнако да развије како би био равноправан учесник света сутрашњице - потребно је инкорпорирати их у формално образовање. ${ }^{14},{ }^{15}$ Проблем у вези са развојем трансмедијске писмености путем информалног учења је у томе што тако стечене трансмедијске компетенције нису систематски и равноправно развијене, већ у складу са индивидуалним праксама и преференцијама корисника. Стога је неопходно развијати трансмедијску писменост у формалном образовању. У супротном, дигитални јаз може лако да буде проширен на јаз партиципације ${ }^{13}$. Наиме, поред дигиталног јаза који упућује на неједнакости у приступу информационо-комуникационим технологијама и медијима, ${ }_{16}$ јаз партиципације настаје као нови расцеп између оних који имаjу компетенције да учествују у савременим медијским и културним токовима, од оних који те компетенције немају. ${ }^{17}{ }^{18}$

Упркос запажању да „у свету презасићеном најразличитијим врстама медија, мало је министарстава образовања који

12 Witte, S., Rybakova, K. and Kollar, C. (2015) Framing Transmedia: Preservice Teachers' Transmedia Interactions with Young Adult Literature Narratives. Signal Journal, 38(1), pp. 27-33.

13 Soriano, C. R. R. (2016) Transmedia mobilization: Agency and literacy in minority productions in the age of spreadable media, Information Society, 32(5), pp. 354-363.

14 Jenkins et al, 2009, исто.

15 Scolari, C. A. (2018) Teens, media and collaborative cultures: exploiting teens' transmedia skills in the classroom, Barcelona: Universitat Pompeu Fabra.

16 Дигитални јаз је јаз који настаје између оних који имају могућност приступа и коришћења информационо-комуникационих технологија и информација и оних који то немају (Webster, 2014), а води томе да они који су економски, образовно, територијално, полно или класно привилеговани могу проширити своје предности употребом нових медија и технологија.

17 Jenkins, H. (2006) Convergence Culture, New York: University Press.

18 Hoffmann, C. P., Lutz, Ch. and Meckel, M. (2015) Content Creation on the INTERNET: A Social Cognitive Perspective on the Participation Divide, Information, Communication \& Society, 18, pp. 696-716. 
медијску писменост третирају као приоритет“, ${ }^{19}$ ипак постоје бројне позитивне иницијативе и праксе (транс)медијског описмењавања. У Великој Британији и Финској медијске студије део су националног основног и средњег образовања, а у Сједињеним Америчким Државама следе се успостављени стандарди трансмедијских компетенција ${ }^{20}$ На интернационалном нивоу, Европски парламент је дигиталну компетенцију усвојио као једну од кључних за доживотно учење ${ }^{21}$ а дефинисана је и дигитална компетенција потребна наставном особљу свих нивоа образовања. ${ }^{22}$ Са друге стране, у многим мање развијеним земљама, попут Републике Србије, иницијативе се још увек задржавају на нивоу доношења стратешких докумената са спорадичном реализацијом у пракси. Због тога у овом раду заговарамо да се развој трансмедијске писмености уведе у оквиру националних система формалног и неформалног образовања, заједно са пажљивом изградњом стратегија и дефинисања стандарда трансмедијских компетенција.

\section{Партиципачија публике у културном животу у дигиталном добу}

Партиципација у култури, по Тамари Вученовић, одражава се „у продукцији културних артефаката, у прикупљању података и садржаја из области културе, на партиципирање у промоцији и презентацији културне баштине, као и у креирању и реализацији програма културе, на партиципацију у процесима чувања и заштите културних ресурса итд." 23 Иако постоји знатно дуже у свом аналогном, физичком облику, са растућом применом дигиталних интерактивних медија долази до нагле експанзије у начинима, формама и могућностима за партиципацију у култури. Партиципација публике у култури се јавља у мноштву облика, од визуелних

\footnotetext{
19 Scolari, p. 4.
}

20 Kubey, R. and Baker, F. (1999) Has media literacy found a curricular foothold, Education Week, pp. 19-56

21 Carretero, Vuorikari and Punie (2017) DigComp 2.1: The Digital Competence Framework for Citizens with eight proficiency levels and examples of use, doi: $10.2760 / 38842$.

22 Redecker, C. (2017) European Framework for the Digital Competence of Educators: DigCompEdu, Punie, Y. (ed). EUR 28775 EN. Publications Office of the European Union, Luxembourg.

23 Вученовић, Т. (2016) Библиотека као носилаи партиципатиених пракси у култури у конпексту информационог друитва, Докторска дисертација, Београд: Филозофски факултет, страна 132. 
форми експресије, ${ }^{24}$ преко виртуелних симфонија и хорова, ${ }^{25}$ до креативног сарадничког писања. ${ }^{26}$

Користећи нове, дигиталне медије, публика данас не само да може брзо, тренутно и јефтино да приступи садржајима и информацијама из области културе, већ да их дели и њима манипулише, па и да учествује у различитим креативним активностима. На различите начине, публика превазилази традиционалну улогу посматрача и добија улогу учесника у стваралачком акту, па чак и коаутора. Поред приступачности и рецепције културног садржаја, интензивира се акт укључивања публике у дело. ${ }^{27}$

Као резултат олакшане и учестале репродукције садржаја од стране онлајн корисника, долази до дестабилизације појмова оригинала и копије културног добра. Кружењем културног и уметничког добра међу корисницима на интернету, њиховим модификацијама и деконтекстуализацијама (променама првобитног контекста), она еволуирају и настају нова добра, чиме се померају постојеће границе културне продукције ${ }^{28}$ Наиме, кружењем у мрежи садржај губи коначност: са сваким новим комуникационим циклусом он добија нове слојеве значења и нову примену. Према томе, садржаји мреже подложни су сталној реинтерпретацији, адаптацији и ко-креирању, а чувена идеја о „отвореном делу” Умберта Ека $^{29}$ добија нову димензију.

Поред тога, кроз културну партиципацију уноси се различитост перцепција и сагледавања стварности што је пресудно за стваралаштво и обогаћивање уметничке сфере. У складу са тим, Мануел Кастелс (Manuel Castells) истиче да се у умреженом друштву јавља култура протока комуникације, „развијена на основу заједничког веровања у моћ умрежавања и синергије добијене давањем другима и добијањем од других" ${ }^{30}$ Кастелс овим адресира једну од најзначајнијих

24 Literat, I. and Glăveanu, V. P. (2016) Same but Different? Distributed Creativity in the Internet Age, Creativity. Theories - Research-Applications, 3(2), pp. 330-342.

25 Cayari, Ch. Music Making on YouTube, in: The Oxford Handbook of Music Making and Leisure, eds. Mantie, R. and Smith, G. D. (2016), pp. 467-488.

26 Jenkins (2006), нав. дело.

27 Ebare, S. (2004) Digital music and subculture: Sharing Files, Sharing Styles, In First Monday, 9(2); Преузето 19. маја 2017. године са сајта http://www. firstmonday.org/issues/issue9_2/ebare/index.html

28 Lessig, L. (2008) Remix: Making Art and Commerce Thrive in a Hybrid Economy, New York: Penguin Press.

29 Eco, U. (1989) The open work. Cambridge, Mass, Harvard University Press.

30 Castells, M. (2000) The Rise of the Network Society, Cambridge: Blackwell Publishers, Inc, p. 62. 
карактеристика умрежене културе: дељење вредности - размена, интеракција и ко-конструкција значења, и то активним деловањем у овом процесу интеракције. Управо се на овој ко-конструкцији темељи нова пракса онлајн културног стваралаштва.

\section{Пирамида културне партиципачије}

На основу претходне расправе, приметно је да се учешће публике у стварању културних дела путем нових медија, остварује на различите начине. Партиципација у култури је слојевита и може се посматрати и кроз варијетет слободе који учесници остварују у интеракцији са садржајем и другим учесницима. Дискутујући о ширем феномену медијске партиципације, Милер (Müller) објашњава да степен учешћа зависи од степена структурирања интеракције, односно контроле над медијском продукцијом. ${ }^{31}$ Како то Милер назива, у структурираном простору партиципације, може се разликовати скала од потпуно структуриране и усмераване до потпуно слободне партиципације. Висока форма партиципације подразумева да корисници имају велику слободу у дефинисању садржаја и начина његовог креирања, док у нижим формама партиципације медији намећу корисницима унапред дефинисане форме учешћа. Слично томе, Јоана Литерат (Ioana Literat) ${ }^{32}$ је поделила партиципацију публике у култури и уметности на три нивоа: рецептивни, извршни и продукцијски (Слика 1). ${ }^{33}$

Рецептиван модел је најнижи облик креативног ангажовања и није делатне, већ контемплативне природе. Публика прима завршен производ (нпр. уметничка слика, позоришна представа, музичко дело, итд). Учешће се овде своди на декодирање и интерпретирање културног добра, али не и на учешће у његовом стварању. Према класификацији медијске публике коју нуди Соња Ливингстон, ова публика је као објекат, остаје у приватној сфери, а њена активност рецепцијске природе је идентитетски-интерпретативна, тј одређена је идентитетским факторима. ${ }^{34}$

31 Müller, E. (2009) Spaces of Participation: Interfaces, Conventions, Routines, Proceedings Media in Transition 6. Boston: MIT.

32 Literat, I. (2012) The Work of Art in the Age of Mediated Participation: Crowdsourced Art and Collective Creativity, International Journal of Communication 6, pp. 2962-2984.

33 У оквиру ове дискусије Литерат поделу илуструје примерима, који су делимично укључени у даљем тексту, а делимично су и уведени нови, следећи њену логику.

34 Livingstone, S. (2013) The Participation Paradigm in Audience Research, The Communication Review, 16 (1-2), pp. 21-30. 
ЈАСМИНА АРСЕНИЈЕВИЋ И АНА МИЛОЈЕВИЋ

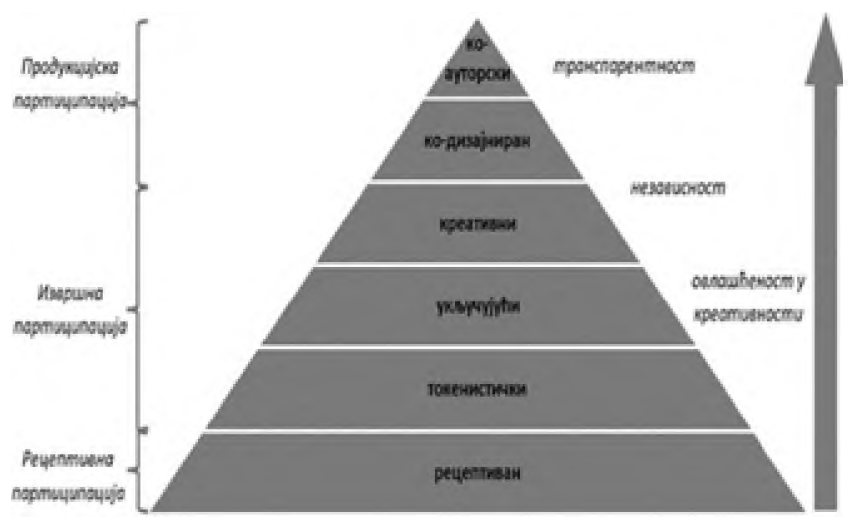

Слика 1. Пирамида партиципације: Шематски приказ нивоа партиципације у култури; Извор: Literat, I. (2012) The Work of Art in the Age of Mediated Participation: Crowdsourced Art and Collective

Creativity, International Journal of Communication 6, p. 2976.

Следи извршни ниво партиципације публике, који се заснива на генерисању и уклапању парцијалних активности појединаца које су оријентисане на одређене задатке. Другим речима, корисници се укључују у унапред осмишљени пројекат, и у високо структу ираном простору партиципације остварују мноштво микродоприноса. Литерат даље разлаже извршни ниво на три подтипа. ${ }^{35}$

Најнижи облик извршне укључености је токенистичке природе, која подразумева нејасне, недијалошке, микропартиципације појединаца у унапред осмишљеном пројекту. Појединци се укључују у пројекат а да при томе нису упознати у коначни исход (партиципације или пројекта) и немају увид у доприносе других појединаца.

Тренд такозваних crowdsourced ${ }^{36}$ пракси, који се остварују у свим сферама креативног изражавања, од визуелне уметности до писања, представља извор многих примера токенистичке партиципације у култури и уметности. ${ }^{37}$ Један од примера представља пројекат у којем је компилирано више од 2000 звучних записа аматера у извођењу песме Daisy Bell $^{38}$. Приликом суделовања у снимању овог виртуелног хора учесници нису имали сазнања о крајњој намери пројекта,

\section{Literat, исто.}

36 Термин crowdsource први је сковао Џеф Хоу (Jeff Howe), подразумевајући чин организације која преусмерава функције коју су раније обављали њени запослени на недефинисане (и генерално велике) мреже људи у форми отвореног позива; Howe, (2006), р. 5.

37 Literat, исто.

38 Пројекат је детаљно описан на видео клипу: https:/www.youtube.com/ watch? $=\mathrm{Gz} 4 \mathrm{OTFeE} 5 \mathrm{JY}$ 
а контрола процеса и стварање исхода у потпуности су потицали од иницијатора пројекта - алфа уметника.

Следећи облик у оквиру рецептивне партиципације је $y \kappa љ y$ чyjyhu. Њега карактерише високо и строго структуирано учешће појединаца, али и повећана транспарентност стваралачког процеса. За разлику о токенистичког нивоа, у укључујућем облику онлајн културне партиципације, учесници знају сврху пројекта и своју улогу у њему.

Crowdsourced уметност се може јављати и као укључујући облик партиципације публике. Један од уметничких праваца, који је доживео изузетан раст у време изолације током светске пандемије вируса Ковид 19, јесте колективно и сарадничко стварање музике путем мреже. Међу првим примерима укључујућег облика партиципације у внду crowdsourced уметности је виртуелни хор модерног композитора Ерика Вајтејкра, у којем се компилује и рекомбинује у колективну изведбу неколико хиљада снимака људи који изводе исту песму (нпр. „Лет у рај” укључује више од 8.400 аудио снимака, преко 5.900 певача из 101 земље $^{39}$ ). Укључујућа партиципација се практикује и у класичној музици. Виртуелне симфоније постају један од чешћих начина учешћа у музици. ${ }^{40}$ Илустративан пример виртуелне симфоније, представља изведб́а дела „Пачелбелов Канон Д” у којој је учествовало 106 музнчара из тридесет земаља. ${ }^{41}$

Многи примери укључујуће партиципације се могу пронаћи и у сфери филмске уметности. Укључивањем публике у различите сегменте филмске продукције трага се за новим идејама и ресурсима креативности. Као пример се може издвојити пионирски, експериментални пројекат Тима Бартона у изради сценарија за филм Cadavre Exquis. Сваки учесник надовезао би се на претходни текст, а Бартон је свакога дана бирао по један, најбољи твит, све док наставак приче није био склопљен. ${ }^{42}$ Литерат ${ }^{43}$ као пример укључујућег пројекта скреће пажњу на „Џони Кеш” - анимирани филм који је састављен од уметничких слика од преко 250.000 појединаца из 172 земље и пропраћен најпознатијим нумерама музичара Џонија Кеша. ${ }^{44}$

$39 \mathrm{https}: / /$ www.youtube.com/watch?v=Y8oDnUga0JU

40 Cayari, исто.

$41 \mathrm{https}: /$ www.youtube.com/watch?v=PsHRaOd0v7A

42 www.burtonstory.com; https://www.atlargeinc.com/insights/tweet-tale-timburton

43 Literat, исто.

44 Више о филму на саjту: http:/www.aaronkoblin.com/project/johnny-cashproject 
Највиши облик извршног модела учешћа јесте креативан: експресивно учешће у оквиру унапред дизајнираног пројекта. Иако и даље ангажовани у унапред осмишљеном пројекту, и са одрећеним ограничењима, појединци који стваралачки доприносе креирању дела у оквиру креативног извршног модела имају вишу могућност личне експресије у поређењу са укључујућим и токенистичким. ${ }^{45}$ На пример, публика је у пројекту снимања филма „Живот у једном дану"46, имала већу независност него публика претходних примера, а ток и резултат пројекта мање је усмераван од стране неког центра. Филм је сачињен тако што су учесници из целог света унапред одређеног датума и истовремено, снимали кратак видео материјал који приказује њихов живот тог специфичног дана. Филм је уређен у документарац ${ }^{47}$ и оцењен као историјски експеримент у стварању највећег светског филма од стране корисника. ${ }^{48}$

Коначно, у највишем, продукцијском нивоу партиципације у култури и уметности, појединци имају утицај на дизајн коначног дела. Публику која узима овај облик учешћа Сoња Ливингстон сврстава у позицију субјекта: врста активне и ангажоване публике која излази из приватне у јавну сфеpy. ${ }^{49}$ Манифестује се у два облика: ко-дизајнирано учешће и коауторско учешће.

Ко-дизајниран облик подразумева да су учесници позвани да се укључе у са̂мо креирање дизајна или структуре пројекта. Wiki Painting је онлајн колаборативно сликање путем посебне интернет платформе, у којем корисници-уметници немају ограничења у броју или врсти измена које уносе у оквиру заједничке слике. ${ }^{50}$

Тек у продукцијском моделу учешћа корисници имају контролу и над дизајнирањем производа, структурирање простора партиципације је најмање, а у складу са тим ниво партиципације је највиши. Милер као пример наводи друштвену мрежу Јутјуб (Youtube), где су форме учешћа корисника који постављају, деле, коригују, коментаришу, анализирају и заједнички стварају видео садржај, колективно

\footnotetext{
45 Literat, исто.

46 Који су продуцирали Ридли Скот и Кевин Мекдоналд (Ridley Scott, Kevin Macdonald), признати у светској кинематографији. Филм се може погледати на сајту: http://www.youtube.com/user/lifeinaday

47 Филм је расположив на сајту: https://www.youtube.com/ watch? $\mathrm{v}=$ WwNV1Nt9iDk

48 Literat, исто.

49 Livingstone, исто.

50 Literat, исто.
} 
обликоване од стране њихове властите, рутинске праксе, са минималном асистенцијом и упливом медијских структура у дизајнирању комуникационог чина. ${ }^{51}$

Ко-ауторски модел подразумева да се ангажовање учесника формално признаје и награђује. За сада, како закључује Литерат, овакви примери још увек не постоје у пракси и још увек се очекује реализација највишег замисливог модела партиципације у уметности - препознавање и признавање ауторства над партиципативном продукцијом.

\section{Трансмедијска писменост као детерминанта културне партиципације}

Како показује пирамида партиципације, потенцијал који нуди култура умреженог друштва како на индивидуалном тако и на колективном нивоу изузетно је велики. Међутим, пирамида је одабрана за приказ форми партиципације зато што својим обликом одсликава структуру доприноса публике: најчешћи примери учешћа публике су смештени у најширем делу пирамиде, у њеној основи, док се на врху пирамиде налазе активности малог броја учесника. Врх пирамиде поседује највиши креативни потенцијал из којег проистичу ретки примери највредније уметничке продукције. Другим речима креативни допринос стваралаштва на рецепцијском и извршном нивоу је најнижи, док са померањем према врху пирамиде квантитативни удео продукције опада, а квалитативни расте. Логика која стоји иза пирамиде партиципације аналогна је правилу палца у медијској партиципацији. Наиме, од $1 \%$ најактивнијих корисника долази $90 \%$ садржаја на интернету, од 9\% њих који повремено доприносе долази $10 \%$ садржаја, док $90 \%$ корисника не даје никакав допринос осим рецепцијског. ${ }^{52}$

Дакле, сваки покушај поспешивања онлајн учешћа у култури мора имати у виду логику пирамиде која подразумева да је за велики допринос култури потребна или мања продукција велике вредности или већа продукција мање вредности. У складу са тим, предност онлајн партиципације је у томе што олакшава процес укључивања и оних чланова публике који имају мање уметничке и креативне капацитете за стваралачки чин, али који мноштвом својих активности увећавају културни свет. Онлајн партиципација тако представља замајац развоја инклузивнијег, антиелитистичког

\footnotetext{
51 Müller, исто.

52 Nielsen, J. (2006) Participation inequality: Encouraging more users to contribute, Jakob Nielsen's alertbox, p. 9.
} 
типа креативне продукције, чија се вредност подиже кроз сарадњу и активирање што већег броја учесника.

Дакле, ефективност партиципације у култури умногоме зависи од броја учесника који се могу укључити, слободе које могу практиковати у процесу стваралаштва, али и од индивидуалних способности или компетенција за учествовање, које припадају палети компетенција које се подводе под дигиталну или трансмедијску писменост.

Повезаност савремене трансмедијске писмености и партиципације потврђује већина дефиниција трансмедијске писмености, које осцилирају око самосвести, знања и вештина појединца за и критичко деловање и активно учествовање $y$ дигиталној култури. Директну везу између културне партиципације и трансмедијске писмености адресира и Тамара Вученовић у елаборату о библиотеци као носиоцу партиципативне културне праксе, у којој тврди да медијско образовање, као колективни, системски развој медијске писмености „представља полазну основу за креативно и критичко присуство на глобалној мрежи, основу и подстицај за генерисање креативног садржаја, односно предуслов да се у култури и медијима креативно партищипира“" 53

У складу са тим, трансмедијску писменост посматрамо као предуслов за ангажовање у култури, односно повезујемо одређене (трансмедијске) компетенције са нивоима партиципације у циљу указивања на начине поспешивања онлајн културне праксе.

Рецепциони облик партиципације у култури захтева способност публике да критички промишља и анализира садржај културе, способност декодирања, разумевања и тумачења културног или уметничког дела као естетичке поруке. Приликом критичке рецепције дела узима се у обзир и начин на који је дело презентовано, што може утицати на његов ефекат. Разумевање дела односи се и на уочавање тачки гледишта, вредности и емоција које су у то дело уграђени. Затим, разумевање контекста у који је дело смештено, као и могуће промене у значењу дела са измештањем у друге контексте. У пирамиди партиципације рецепција је постављена као најнижи облик у смислу активног, физичког делања, али је ипак психолошки интензивна и често се у литератури одбија став којим се потцењује вредност чина рецепције. Тако Фиске тврди да је и само тумачење садржаја културе активан чин. ${ }^{54}$ Ова способност представља тежиште

53 Вученовић, исто, стр. 105.

54 Fiske, према: Вученовић, исто. 
трансмедијске писмености и обухваћена је у готово свим теоријским разматрањима, а Хенри Џенкинс (Henry Jenkins) је дефинише као сегмент трансмедијске писмености, који називају „просуђивање". ${ }^{55}$

Поред рецепције, свака реинтерпретација, адаптација и модификација дела, одређене су истим критичким и аналитичким компетенцијама које су потребне за рецепцију културних дела, али укључују и друге вештине манипулисања овим делима. Како је више пута наглашено у овом раду, уметност не долази искључиво из креативности и имагинације талентованих појединаца - она може извирати из сарадње мноштва аматера, неетаблираних уметника и других. Стога је за културну партиципацију потребно поседовати способност креативног комбиновања и обогаћивања (ремикса) постојећег садржаја уз помоћ нових медија. Ове вештине Џенкинс дефинише као посебну трансмедијску компетенцију „присвајање" ${ }^{56}$ Подизањем капацитета „присвајања" поједници се оснажују за форме експресије које се заснивају на комбиновању и ремиксовању. Један од занимљивих примера ремикс културе је фанфикција или фановска фикција (енг. fan fiction), односно праксе у којима љубитељи књижевности развијају алтернативне приче и другачије завршетке постојећих дела. Поред комбиновања, способност присвајања подразумева капацитет да се одређени садржај доживи из другачије перспективе, уз препознавање његових могућих латентних значења. ${ }^{57}$

Коначно, продукцијски ниво партиципације, у којем публика има највишу аутономију у стварању културног или уметничког добра, поред наведених медијских компетенција, подразумева и стваралачке способности које су у основи сваког креативног чина. Трансмедијска писменост се налази и у основи стваралаштва, јер укључује способност употребе медија за креирање, артикулисање и комуницирање властитих порука, било ради самоизражавања или у циљу интеракције са људима и утицаја на друге људе. Трансмедијска писменост потребна је корисницима како би били способни да идентификују основне законитости у понашању и комуницирању и разумеју нормативне и етичке односе унутар заједница са којима имају интеракцију, али и да овладају инфраструктуром одређеног медија. Само трансмедијски писмени корисници способни су да артикулишу и објављују

55 Jenkins et al. (2009) исто.

56 Исто.

57 Исто. 
властите ставове на одговарајућем медијуму и учествују у интеркултурном дијалогу.

Код преношења креативног дела, веома је важно разумети механизме комуницирања унутар одређених интересних група и публике, и прилагодити се нормама комуникационе заједнице, што је такође један елеменат трансмедијске писмености. Недостатак ових способности може угрозити могућност појединца да на прихватљив и ефективан начин испољи своју креативност и таленат и да сарађује са другима у културним активностима у онлајн заједницама. За ефективну онлајн интеракцију важно је проналажење адекватне друштвене заједнице на мрежи, као и разумевање социјалних и психолошких фактора које обликују колективна понашања у тим заједницама („умрежавање”). ${ }^{58}$

Етички, морални, културни, верски и вредносни системи играју битну улогу у свакој друштвеној интеракцији, те је веома важна вештина њиховог препознавања и уважавања, што је у основи социјалног аспекта трансмедијске писмености. ${ }^{59}{ }^{60}$ Освешћивање и превазилажење културних и друштвених предрасуда које обликују начин комуникације и интеракције на мрежи је од велике важности. Ова вештина (тзв. „преговарање") ${ }^{61}$ омогућава да приликом културне партиципације превазићемо социјалне баријере у саопштавању својих порука или тумачењу туђих, настале услед обликовања дела у складу са културолошким перспективама.

Коначно, заједничка интеракција која води међусобном инспирисању, допуњавању и мотивисању у оквиру креативног стваралаштва, реализује се услед способности корисника да у интеракцији одступи од индивидуалног идентитета и уживи се у колективни, посматрајући заједницу у којој делује као засебни ентитет. Стварање заједничког дела или решавање проблема у области културе и уметности потребно је посматрати као тимску, а не индивидуалну активност (компетенција „колективна интелигенција”). ${ }^{62}$ На овој способности суизградње се заснива основна предност савремене дигиталне културе, где тежиште лежи на континуираној сарадњи, пре него на чину делања. Кастелс ово назива „синергијом", која стоји у основи културе умреженог друштва. ${ }^{63}$

58 Исто.

59 Ието.

60 Scolari, исто.

61 Jenkins et al. (2009), исто.

62 Ието.

63 Castells, M. (2000) The Rise of the Network Society, Cambridge: Blackwell Publishers, Inc. 
Дакле, социјални аспекти трансмедијске писмености представљају важне комептенције за културну партиципацију ${ }^{64}$ a Џенкинс их операционализује као вештине: „умрежавање”, „преговарање” и „колективна интелигенција”. ${ }^{65}$

Међутим, иако у овом раду истичемо значај трансмедијског описмењавања као стратегије за подизање капацитета за учешће у култури са крајњим циљем обогаћивања културе, морамо се осврнути и на страну структуирања партиципације. Наиме, вредност резултата културне партиципације не налази се само у великом броју појединих микродоприноса публике, већ и у осмишљавању културног или уметничког пројекта, анимирању публике за учешће, надгледањем и регулисањем пројекта и уређивању и уклапању доприноса публике у коначан резултат. Овај уређивачки процес, осим уметничке и стваралачке ангажованости, поседује и елементе планирања, регулације, контроле и формализације. Ову фазу могу реализовати различити субјекти, од независног уметника (,алфа-уметника”), преко самоорганизоване групе учесника из публике, институције културе, до медијске организације. Милер овај процес назива структурирањем простора партиципације, тј. дефинисањем форме партиципације. ${ }^{6}$

Критичари партиципације упозоравају да је овај процес у пракси строго структуриран, али не само из разлога повећања уметничке вредности добра, већ да постоји опасност да је усмераван према профитним интересима медијских корпорација. Теранова ${ }^{67}$, Андрејевић ${ }^{68}$ и Ван Дајк и сарадници ${ }^{69}$ чак сматрају да медијске индустрије прибегавају усмеравању и искоришћавању интерактивног потенцијала партиципативне културе (тзв. завођењу публике) као савременог облика бесплатног креативног, културног и техничког рада. У том смислу трансмедијски писмени појединци способни су да установе и разликују степен уплива трећих лица (медијских корпорација, владајућих тела, приватних лица) ради коришћења и усмеравања њихове партиципације, те

64 Scolari, исто.

65 Jenkins et al. (2009), исто.

66 Müller, исто.

67 Terranova, T. (2000) Free Labor: Producing Culture for the Digital Economy, Social Text 63 (18), pp. 33-57.

68 Andrejevic, M. (2003) The Webcam Subculture and the Digital Enclosure. MediaSpace: Place, Scale and Culture in a Media Age, ed. by Couldry, N. and McCarthy. A, London/New York: Routledge

69 Van Dijck, J., de Waal, M. and Poell, Th. (2018) The Platform Society: Public Values in a Connective World, Oxford: Oxford University Press. 
да избегну замке псеудо-партиципације. ${ }^{70}$ Медијски компетентни корисници су освешћени и слободни да сами доносе одлуке када, како, колико и зашто ће партиципирати, те да у складу са властитим капацитетима и афинитетима бирају заједнице у којима ће учествовати и форме културне партиципације које ће узимати.

\section{Закьучак}

Позитивни ефекти културе и уметности на појединца и друштво познати су у широј научној и стручној литератури. Бројне студије, извештаји и истраживања показују да култура и уметност унапређују здравље и психу људи, ${ }^{71}$ продуктивност и иновативност, да подстичу социјалну инклузију и демократичност, ${ }^{72}$ доприносе заштити животне средине. ${ }^{73}$

Недавна истраживања потврдила су да онлајн креативност и уметност, али и пасивна културна партиципација, позитивно утичу на јачање друштвеног и грађанског ангажовања људи, ${ }^{74,75}$ као и на спремније улагање напора у сврху заштите животне средине. ${ }^{76}$ Услед позитивног утицаја на физичко, ментално и емотивно здравље, култура и уметност се користе и у „лековите” сврхе, попут „терапије уметношћу” и „културе на рецепт", чиме се постижу значајне уштеде на пољу здравствене неге и заштите. ${ }^{77}$ Бројна истраживања

70 Glas, R., Lammes, S., De Lange, M., Raessens, J. and De Vries, I. (2019) The Playful Citizen. An Introduction, in: Glas, R., Lammes, S., De Lange, M., Raessens, J. and De Vries, I. The Playful Citizen. Civic Engagement in a Mediatized Culture, pp. 9-33. Amsterdam: Amsterdam University Press.

71 APPGA (2017) Creative Health: The Arts for Health and Wellbeing. Преyзeто 20. јула 2020. године са сајта: https://www.artshealthandwellbeing.org. uk/appg-inquiry/Publications/Creative_Health_Inquiry_Report_2017.pdf

72 Phillips, S. (2018) The social impact of participation in culture. Преузето 15. јуна 2020. године са сајта: http://mbassociates.org/wp-content/uploads/2018/03/Social-Impact-of-Participation-in-Culture_MB-Associates-submission-22Feb18.pdf

73 Crossick, G. and Kaszynska, P. (2016) Understanding the value of arts \& culture The AHRC Cultural Value Project. Arts and Humanities Research Council, Polaris House: Swindon, Wiltshire; преузето 12. јуна 2020. године ca сајта: https://ahrc.ukri.org/documents/publications/cultural-value-project-final-report/

74 Исто.

75 KEA \& PPMI (2019) Research for CULT Committee - Culture and creative sectors in the European Union key future developments, challenges and opportunities. European Parliament, Policy Department for Structural and Cohesion Policies: Brussels. Preuzeto 17. juna 2020. godine sa sajta: https:/www.europarl.europa.eu/RegData/etudes/STUD/2019/629203/ IPOL_STU(2019)629203_EN.pdf?fbclid=IwAR1z7SGekthiUmStEssgQozlVr1K0ZnBls1ll63KEqCptIk-nwD253QECvM

76 Crossick and Kaszynska, исто, страна 7.

77 APPGA, исто. 
ефеката културне партиципације показала су да се повећавају когнитивне и психолошке перформансе код посматрача-учесника, од којих се најчешће спомиње креативност и иновативност, ${ }^{78}$ критичко мишљење, ${ }^{79}$ а потом способност решавања проблема ${ }^{80}$ и способност сарадње и комуницирања. ${ }^{81}$ Скуп управо ових когнитивних и интерперсоналних вештина дефинисане су и као кључне компетенције за будућност од стране америчке асоцијације за образовање ${ }^{82}$ и европског савета. ${ }^{83}$

У савременој економији у којој креативне индустрије имају значајно, и све перспективније место, у коме је иновирање производа, услуга и процеса рада императив, развој креативности и иновативности људских ресурса представља значајан добитак. Зато културна партиципација, било у виду активног суделовања у креативним и стваралачким активностима, било у виду посматрања, има значајне бенефиције по појединца и заједнице и механизми њеног повећања (посредством дигиталних медија који омогућују увећање круга уживалаца) представљају добродошао корак ка здравијем, продуктивнијем и више демократском друштву.

Како овај рад показује, међутим, потенцијал онлајн културне партиципације одређен је трансмедијском писменошћу корисника. Имајући у виду непосредне и посредне користи учешћа у култури, овај рад истиче да је веома важно радити на развоју колективног трансмедијског описмењавања. У складу са тим, сугерише се системски и интензивни рад на развоју трансмедијске писмености у оквиру формалног образовања. Како би се ово постигло, потребно је доношење јавних политика и изналажење адекватних образовних пракси, са циљем повећања слободне и компетентне партиципације, и то не само у култури и уметности, већ у свим

78 Crossick \& Kaszynska, исто, страна 8.

79 KEA \& РРМІ, исто.

80 APPGA, исто.

81 Varbanova, L. (2011) Cultural participation in education and lifelong learning: a catalyst for personal advancement, community development, social change and economic growth; преузето 17. јуна 2020. године са сајта: http://www.houseforculture.eu/upload/Docs\%20ACP/Accesstoculturepolicysummary August3 12012updatedFormated1.pdf

82 National Education Association (2012) Preparing 21 st century students for a global society: An educator's guide to "the four Cs." Washington, DC; преузето 20. јуна 2020. године са сајта: http://www.nea.org/assets/docs/AGuide-to-Four-Cs.pdf

83 European Council (2018) Council Recommendation of $22 \mathrm{May} 2018$ on Key Competences for LifeLong Learning, 2018/C 189/01, Brussels, Belgium European Council. 
друштвеним процесима посредованим новим медијима у данашњем, умреженом, дигиталном друштву.

У циљу развоја трансмедијске писмености у Републици Србији се предлаже адекватно и континуирано управљање људским ресурсима, повећање технолошке опремљености школа и развој флексибилног школског курикулума у коме би се трансмедијско описмењавање спроводило кроскурикуларно у свим нивоима формалног образовања. Веома важно је развијање адекватних педагошких пракси, под чиме подразумевамо пре свега укључивање информалних стратегија учења младих у формални систем образовања. Наиме, у пракси великог броја земаља препознато је да је информално учење доминантан, али не и једини фактор у стицању трансмедијских компетенција код младих. Тако је у великом опсежном интернационалном истраживању уочено да су најзначајније информалне стратегије развоја трансмедијских компетенција младих: учење радећи, решавање проблема, имитирање и симулација, учешће у играма, евалуација туђег рада и подучавање других - све посредством савремених медијских технологија. ${ }^{84}$ Интеграција ових стратегија учења у формално учење је стога неизбежна стратегија у циљу постизања ефективног трансмедијског описмењавања, по ставовима. ${ }^{85,86,87}$ Коначно, кључ сваке врсте реформа лежи у људским ресурсима, те је изнад свега важно изградити климу и културу у образовном систему и институцијама (али и у друштву уопште) у којима је развијена свест о неопходности трансмедијског описмењавања. Налази истраживања у Србији потврђују овај став, указујући да и сами наставници сматрају да је највећа препрека реформама ьихова незаинтересованост, неинформисаност и неприпремљеност. ${ }^{88} \mathrm{У}$ складу са тим, кључно је изграђивање система укључивања, информисања, мотивисања и адекватног и континуираног усавршавања наставника. Поред тога, потребно је изградити управљачке механизме попут дефинисања минималних стандарда медијских компетенција наставника и ученика, успостављање система награђивања и контроле у оквиру

\footnotetext{
84 Scolari, исто.
}

85 Исто.

86 Jenkins et al. (2009), исто.

87 Black, J., Castro, J. C. and Ching-Chiu, L. (2015) Youth practices in digital arts and new media: Learning in formal and informal settings, New York: Palgrave.

88 Valić Nedeljković, D., Janjatović Jovanović, M., Petković, B. i Bašić Hrvatin, S. (2019) Iskustva i nove mogućnosti za implementaciju medijske i informacione pismenosti u osnovne i srednje škole u Srbiji, Novi Sad: Novosadska novinarska škola. 
JАСМИНА АРСЕНИЈЕВИЋ И АНА МИЛОЈЕВИЋ

школског менашмента и омогућавање флексибилности у раду наставника и прилагођавању курикулума.

\section{ЛИТЕРАТУРА:}

Andrejevic, M. (2003) The Webcam Subculture and the Digital Enclosure. MediaSpace: Place, Scale and Culture in a Media Age, ed. Couldry N. and McCarthy, A., London/New York: Routledge.

APPGA - All-Party Parliamentary Group on Arts, Health and Wellbeing (2017) Creative Health: The Arts for Health and Wellbeing. Преузето 20. јула 2020. године са сајта: https://www.artshealthandwellbeing.org.uk/appg-inquiry/Publications/Creative_Health_Inquiry_Report_2017.pdf

Arsenijević, J. i Andevski, M. Kreativnost u prostoru interneta, u: Digitalne medijske tehnologije i društveno-obrazovne promene 5 , ur. Pralica, D. i Šinković, N. (2015), Filozofski fakultet: Novi Sad, str. 11-21.

Beech, D. (2010) Don't Look Now! Art After the Viewer and Beyond Participation, in J. Walwin (ed.), Searching for art's new publics (pp. 15-30), Bristol, UK: Intellect Ltd.

Black, J., Castro, J. C. and Ching-Chiu, L. (2015) Youth practices in digital arts and new media: Learning in formal and informal settings, New York: Palgrave.

Carretero, S., Vuorikari, R. and Punie, Y. (2017) DigComp 2.1: The Digital Competence Framework for Citizens with eight proficiency levels and examples of use, Luxembourg: Publications Office of the European Union.

Castells, M. (2000) The Rise of the Network Society, Cambridge: Blackwell Publishers, Inc.

Cayari, Ch. Music Making on YouTube, in: The Oxford Handbook of Music Making and Leisure, eds. Mantie, R.and Smith, G. D. (2016), pp. 467-488.

Crossick, G. and Kaszynska, P. (2016) Understanding the value of arts $\&$ culture The AHRC Cultural Value Project, Arts and Humanities Research Council, Polaris House: Swindon, Wiltshire; preuzeto 12. juna 2020. godine sa sajta: https://ahrc.ukri.org/documents/publications/ cultural-value-project-final-report/

Ebare, S. (2004) Digital music and subculture: Sharing Files, Sharing Styles. In First Monday, 9(2); преузето 19. маја 2017. године са сајтa http://www.firstmonday.org/issues/issue9_2/ebare/index.html

Eco, U. (1989) The open work, Cambridge, Mass, Harvard University Press.

European Council (2018) Council Recommendation of 22 May 2018 on Key Competences for LifeLong Leaming, 2018/C 189/01, Brussels, Belgium: European Council. 
ЈАСМИНА АРСЕНИЈЕВИЋ И АНА МИЛОЈЕВИЋ

Fleming, L. (2013) Expanding Learning Opportunities with Transmedia Practices: Inanimate Alice as an Exemplar. Journal of Media Literacy Education 5 (2), pp. 370-377.

Glas, R., Lammes, S., De Lange, M., Raessens, J. and De Vries, I. The Playful Citizen. An Introduction, in: The Playful Citizen. Civic Engagement in a Mediatized Culture, eds. Glas, R., Lammes, S., De Lange, M., Raessens, J. and De Vries, I. (2019), Amsterdam: Amsterdam University Press, pp. 9-33.

Grech, A. (2014) Malta National Lifelong Learning Strategy 2020. Преузето 12. марта 2018. године са сајта: http://www.ncte.org/library/nctefiles/resources/journals/ej/1026-jul2013/ej1026longer.pdf

Hartley, J. (2012) Digital Futures for Cultural and Media Studies, Wiley-Blackwell.

Hobbs, R. (2010) Digital Media Literacy: A Plan of Action, New Delhi: Aspen Institute.

Hoffmann, C. P., Lutz, Ch. and Meckel, M. (2015) Content Creation on the INTERNET: A Social Cognitive Perspective on the Participation Divide. Information, Communication \& Society, 18, pp. 696-716; DOI: 10.1080/1369118X.2014.991343

Howe, J. (2006) Crowdsourcing: A Definition, in: Crowdsourcing: Tracking the Rise of the Amateur, преузето 15. јануара 2018. године ca cajтa: http://crowdsourcing.typepad.com/cs/2006/06/crowdsourcing_a.html

Hull, G. (2004) Youth culture and digital media: New literacies for new times, Research in the Teaching of English, 38(2), pp. 229-233.

Jenkins, H. (2006) Convergence Culture, New York: University Press.

Jenkins, H., Ito, M. and Boyd, D. (2015) Participatory Culture in a Networked Era, Cambridge: Polity Press.

Jenkins, H., Purushotma, R., Weigel, M., Clinton, K. and Robinson, A. (2009) Confronting the Challenges of Participatory Culture: Media Education for the 21 st Century. Cambridge, MA: The MT Press.

KEA PPMI (2019) Research for CULT Committee - Culture and creative sectors in the European Union key future developments, challenges and opportunities. European Parliament, Policy Department for Structural and Cohesion Policies: Brussels. Preuzeto 17. juna 2020. godine sa sajta: https://www.europarl.europa.eu/RegData/etudes/STUD/2019/629203/IPOL STU(2019)629203_EN.pdf?fbclid=IwAR1z7SGekthiUmStEssgQozlVr1K0ZnB1s11163KEqCptIk-nwD253QECvM

Kubey, R. and Baker, F. (1999) Has media literacy found a curricular foothold. Education Week, pp. 19-56.

Lessig, L. (2008) Remix: Making Art and Commerce Thrive in a Hybrid Economy, New York: Penguin Press. 
Literat, I. (2012) The Work of Art in the Age of Mediated Participation: Crowdsourced Art and Collective Creativity, International Journal of Communication 6, 2962-2984.

Literat, I. and Glăveanu, V. P. (2016) Same but Different? Distributed Creativity in the Internet Age, Creativity. Theories - Research-Applications,3(2), pp. 330-342.

Livingstone, S. (2013) The Participation Paradigm in Audience Research. The Communication Review, 16(1-2), 21-30. https://doi. org/10.1080/10714 421.2013.757174

Livingstone, S. (2015) Digital Skills for EU Citizens and Consumers; Преузето 2.12.2020. са URL адресе: http://eprints.lse.ac.uk/80765/.

Mihailidis, P. (2019) Media Literacy and the Emerging Citizen: Youth, Engagement and Participation in Digital Culture, New York: Peter Lang.

Müller, E. (2009) Spaces of Participation: Interfaces, Conventions, Routines, Proceedings Media in Transition 6; Boston: MIT.

National Education Association (2012) Preparing 21st century students for a global society: An educator's guide to "the four Cs." Washington, DC; преузето 20. јуна 2020. године са сајта: http://www. nea.org/assets/docs/A-Guide-to-Four-Cs.pdf

Nielsen, J. (2006) Participation inequality: Encouraging more users to contribute, Jakob Nielsen's alertbox, 9.

Phillips, S. (2018) The social impact of participation in culture. Пpeyзето 15. јуна 2020. године са сајта: http://mbassociates.org/wp-content/uploads/2018/03/Social-Impact-of-Participation-in-Culture_MBAssociates-submission-22Feb18.pdf

Redecker, C. (2017) European Framework for the Digital Competence of Educators: DigCompEdu, ed. Punie, Y. EUR 28775 EN. Publications Office of the European Union, Luxembourg doi: 10.2760/159770, JRC107466

Scolari, C. A. (2018) Teens, media and collaborative cultures: exploiting teens 'transmedia skills in the classroom, Barcelona: Universitat Pompeu Fabra.

Soriano, C. R. R. (2016) Transmedia mobilization: Agency and literacy in minority productions in the age of spreadable media. Information Society, 32(5): 354-363. DOI: https://doi. org/10.1080/01972243.20 16.1212620

Spicer, B. (2017) Digital Literacy: The New Pillar of a Child's Education? преузето 18. јула 2020. године са сајта: https://blog. myon.com/blog-post/digital-literacy-new-pillar-child\%E2\%80\%99seducation

Terranova, T. (2000) Free Labor: Producing Culture for the Digital Economy, Social Text 63 (18): 33-57. DOI: 10.1215/01642472-182_63-33 
ЈАСМИНА АРСЕНИЈЕВИЋ И АНА МИЛОЈЕВИЋ

The All-Party Parliamentary Group on Arts, Health and Wellbeing APPG (2017) Creative Health: The Arts for Health and Wellbeing, preuzeto 16. juna 2020. godine sa sajta: https://www.culturehealthandwellbeing.org.uk/appg-inquiry/

Valić Nedeljković, D., Janjatović Jovanović, M., Petković, B. i Bašić Hrvatin, S. (2019) Iskustva i nove mogućnosti za implementaciju medijske $i$ informacione pismenosti u osnovne $i$ srednje škole u Srbiji. Novi Sad: Novosadska novinarska škola.

Van Dijck, J., de Waal, M. and Poell, Th. (2018) The Platform Society: Public Values in a Connective World, Oxford: Oxford University Press.

Varbanova, L. (2011) Cultural participation in education and lifelong learning: a catalyst for personal advancement, community development, social change and economic growth; преузето 17. јуна 2020. године са сајта: http://www.houseforculture.eu/upload/Docs $\% 20$ ACP/AccesstoculturepolicysummaryAugust312012updatedFormated1.pdf

Webster, F. (2014) Theories of The Information Society (четврто издање, први пут објављено 1995), London and New York: Routledge.

Witte, S., Rybakova, K. and Kollar, C. (2015) Framing Transmedia: Pre-service Teachers' Transmedia Interactions with Young Adult Literature Narratives, Signal Journal, 38(1), pp. 27-33.

Zukin, C., Keeter, S., Andolina, M., Jenkins, K., Delli C. and Michael X. (2006) A New Engagement? Political Participation, Civic Life, and the Changing American Citizen, Oxford University Press.

Вученовић, Т. (2016) Библиотека као носилаи партиципатиених пракси у култури у контексту информаиионог друитва. Докторска дисертација, Београд: Филозофски факултет.

Лесиг, Л. (2006) Слободна култура, Београд: Службени гласник.

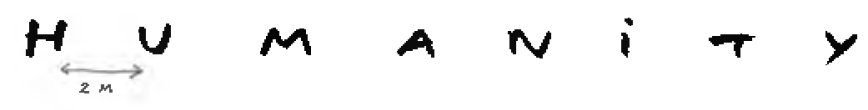

Dan Perjovschi, Virus Diary Humanity, marker on paper, 2020, courtesy the artist 
JАСМИНА АРСЕНИЈЕВИЋ И АНА МИЛОЈЕВИЋ

Jasmina Arsenijević and Ana Milojević

Teacher Training College, Kikinda; University in Belgrade, Faculty of Political Sciences - Department for Journalism and Communicology, Belgrade

\title{
TRANSMEDIA LITERACY IN THE SERVICE OF CULTURAL DEVELOPMENT
}

\begin{abstract}
This paper considers changes caused by new technologies that enable an increasing participation of average Internet users in the field of cultural production. From the perspective of pyramidal participation, different forms of achieving user participation in culture are presented, according to the level of freedom they achieve, that is the structure of the relationships in participation. The main argument of the paper is that development of culture can be accelerated by increasing participation in cultural production. Accordingly, a link between participation pyramid and the competencies related to transmedia literacy is made, in order to point out the potential that transmedia literacy can have for enriching global culture.
\end{abstract}

Key words: online participation, culture, art, transmedia literacy
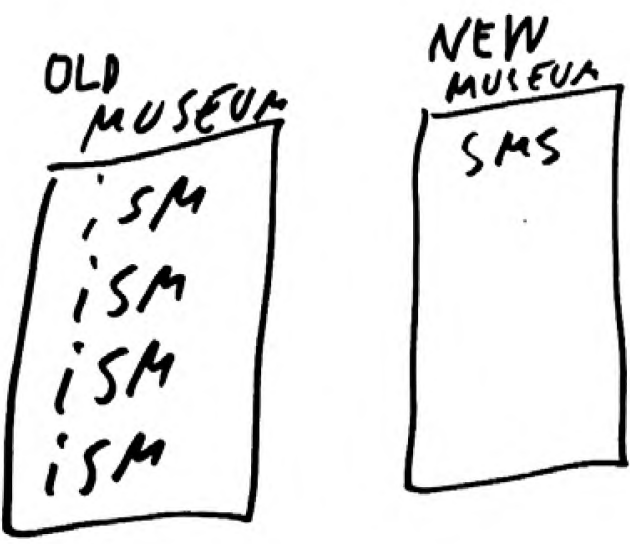

Dan Perjovschi, Museum old \& new, marker on paper, 2010, courtesy the artist 